\title{
Numerical Prediction of Heat Transfer Characteristics of Nanofluids in a Minichannel Flow
}

\author{
Arjumand Adil, Sonam Gupta, and Pradyumna Ghosh
}

Department of Mechanical Engineering, Institute Of Technology (Banaras Hindu University), Varanasi 221005, India

Correspondence should be addressed to Pradyumna Ghosh; pradyumna_ghosh@rediffmail.com

Received 31 January 2013; Revised 17 September 2013; Accepted 12 December 2013; Published 4 February 2014

Academic Editor: Neil J. Hewitt

Copyright (C) 2014 Arjumand Adil et al. This is an open access article distributed under the Creative Commons Attribution License, which permits unrestricted use, distribution, and reproduction in any medium, provided the original work is properly cited.

CFD simulation of the heat transfer and pressure drop characteristics of different nanofluids in a minichannel flow has been explained using FLUENT version 6.3.26. Different nanofluids with nanoparticles of $\mathrm{Al}_{2} \mathrm{O}_{3}, \mathrm{CuO}, \mathrm{SiO}_{2}$, and $\mathrm{TiO}_{2}$ have been used in the simulation process. A comparison of the experimental and computational results has been made for the heat transfer and pressure drop characteristics for the case of $\mathrm{Al}_{2} \mathrm{O}_{3}$-water nanofluid for the laminar flow. Also, computations have been made by considering Brownian motion as well as without considering Brownian motion of the nanoparticles. After verification of the computational model with the experimental results for $\mathrm{Al}_{2} \mathrm{O}_{3}$-water nanofluid, the simulations were performed for the same experimental readings for different nanofluids in the laminar flow regime to find out the heat transfer and pressure drop characteristics.

\section{Introduction}

Nanofluids are engineered colloids made up of a base fluid and the nanoparticles. The introduction of nanoparticles enhances the heat transfer performance of the base fluids significantly. The base fluids may be water, organic liquids (e.g., ethylene, tri-ethylene-glycols, refrigerants, etc.), oils and lubricants, biofluids, polymeric solutions, and other common liquids. The nanoparticle materials include chemically stable metals (e.g., gold, copper), metal oxides (e.g., alumina, silica, zirconia, and titania), oxide ceramics (e.g., $\mathrm{Al}_{2} \mathrm{O}_{3}$, and $\mathrm{CuO}$ ), metal carbides (e.g., SiC), metal nitrides (e.g., AIN, SiN), carbon in various forms (e.g., diamond, graphite, carbon nanotubes, and fullerene), and functionalized nanoparticles [1-5].

The benefits of using nanofluids compared to the conventional base fluids are as follows.

(1) The amount of heat transfer increases as a result of increase in the heat transfer surface area between the particles and fluids.

(2) The pumping power required for the equivalent heat transfer is less than that compared to pure liquids.
(3) The properties like thermal conductivity, density, and so forth may be varied by varying particle concentrations to suit different applications.

The nanofluids have various applications as they provide an efficient thermal energy transfer due to higher heat transfer with comparable pumping power required. Some of these applications are stated as follows.

(1) Heating and cooling of buildings.

(2) Cooling of electronics.

(3) Cooling of welding.

(4) Nuclear systems cooling.

(5) Solar water heating.

(6) Refrigeration (domestic refrigerator, chillers).

(7) Biomedical applications.

(8) Drilling.

(9) Lubrications.

(10) Thermal storage.

The effective physical properties are required to be calculated from the properties of nanoparticles and base fluid. 
Of all the properties, the thermal conductivity is the most important one regarding many applications. Several models have been developed for predicting the thermal conductivity like by Maxwell-Garnett, Hamilton and Crosser, Buongiorno, Koo and Kleinstreuer, Keblinski et al., Azizian et al., Jang and Choi, Kumar et al., Patel et al., and several others. The classical models like Maxwell-Garnett and Hamilton-Crosser models have failed to predict the significant enhancement in the thermal conductivity of the nanofluids. This shows that other mechanisms are also present which increases the thermal conductivity and in turn enhances the heat transfer in nanofluids.

Buongiorno [6] proposed a mathematical model by considering nanoparticle/base fluid slip and he showed that Brownian motion and thermophoresis are the main mechanisms for this slip mechanism. But, Koo and Kleinstreuer [7] proved that Brownian motion was the more important phenomena. Also, the thermal conductivity of nanofluids has strong temperature dependence.

Keblinski et al. [8] proved that the direct influence of the Brownian motion of the nanoparticles via diffusion is negligible. Azizian et al. [9] did experimental investigations that support the indirect influence of the Brownian motion by intensification of microconvection of fluid around separate nanoparticles. Jang and Choi [10] proposed a model based on Brownian motion induced nanoconvection.

The model proposed by Kumar et al. [11] based on Brownian motion overestimated the contribution of Brownian motion to heat flow. But Patel et al. [12] improved the model proposed by Kumar et al. by incorporating the effect of microconvection due to particle movement.

There has been miniaturization of electronic components and development of systems microcomponents and devices for diverse applications like biomedical devices, MEMS, and so forth. The need for micro- and minichannels arose to eliminate overheating in the microcomponents, by having heat transfer as fast as possible in order to ensure increased reliability and stability.

The purpose of the work done here was to computationally predict the heat transfer and pressure drop characteristics of $\left(\mathrm{Al}_{2} \mathrm{O}_{3}+\mathrm{H}_{2} \mathrm{O}\right)$ nanofluid in a minichannel flow under constant heat flux. The experiment was done for different concentrations of the nanofluid-2\% and $3 \%$ and distilled water for laminar flow. The minichannel that was used was of $0.87 \mathrm{~mm}$ inner diameter, which is the smallest available diameter for experimentation and closer to electronic cooling applications. In the computational simulation, the nanofluid was considered as a homogeneous mixture of the base fluid and the nanoparticles. The computational simulations were performed with and without considering the Brownian motion of the nanoparticles. There is a strong enhancement in the effective thermal conductivity when the Brownian motion of nanoparticles is considered.

After the computational results for $\mathrm{Al}_{2} \mathrm{O}_{3}$-water nanofluid were compared with the experimental results, the validity of the computational model used was verified. Then, computational simulations were performed for the same experimental readings for different fluids with nanoparticles of $\mathrm{CuO}, \mathrm{SiO}_{2}$, and $\mathrm{TiO}_{2}$ to find out the heat transfer characteristics.

\section{Materials and Methods}

2.1. Description of the Experiment. The experimental setup consisted of minichannel with inner diameter of $0.87 \mathrm{~mm}$. A mercury manometer was used to calculate the pressure drop across the minichannel. $\mathrm{Al}_{2} \mathrm{O}_{3}$-water nanofluid with different concentrations of $2 \%$ and $3 \%$ is passed through the different minichannels. A container with submersible pump stores the nanofluid. The pump pushes the nanofluid up to the collecting tank and variable flow rates can be obtained by adjusting the height of the tank. For obtaining lesser flow rates at the same height, a bypass valve is used. Seven equally spaced thermocouples ( $\mathrm{K}$ type) have been attached to the outer surface of the minichannel wall. These thermocouples are further connected to the temperature indicator. A coiled wire heater provides constant heat flux to the minichannel, whose voltage is regulated by a voltage variac. Glass wool and asbestos are used to insulate the minichannel. Figure 1 shows the schematic diagram of the experimental setup. Homogeneity of the mixture has been tested by measuring density of the nanofluid at inlet and outlet of the minichannel which is within $1 \%$ alteration.

2.2. Thermophysical Properties of Nanofluids. The thermophysical properties of nanofluids, namely, density, thermal conductivity, specific heat, and viscosity, have been calculated by using the formulas as summarized below.

The density of the nanofluids has been calculated by using the formula given by Buongiorno [6]:

$$
\rho_{n f}=(1-\varphi) \rho_{f}+\varphi \rho_{p}
$$

For higher concentration, density as well as mass flow rate increases as the average velocity of the flow is determined by the centroid of the liquid filled overhead tank.

The specific heat of the nanofluid has also been calculated by using the formula which was used by Buongiorno [6] after modifying a previous formula. The original correlation is given as follows:

$$
C_{n f}=(1-\varphi) C_{f}+\varphi C_{p}
$$

The correlation by Buongiorno that was used here is as follows:

$$
C_{n f}=\frac{(1-\varphi) \rho_{f} C_{f}+\varphi \rho_{p} C_{p}}{\rho_{n f}} .
$$

The thermal conductivity equation given by Hamilton and Crosser [13] has been used for calculation purposes for the case when Brownian motion was not considered. Although this thermal conductivity model was given for mixtures containing micrometer sized particles, Zhang et al. [14] have shown that this model predicts the thermal conductivity 


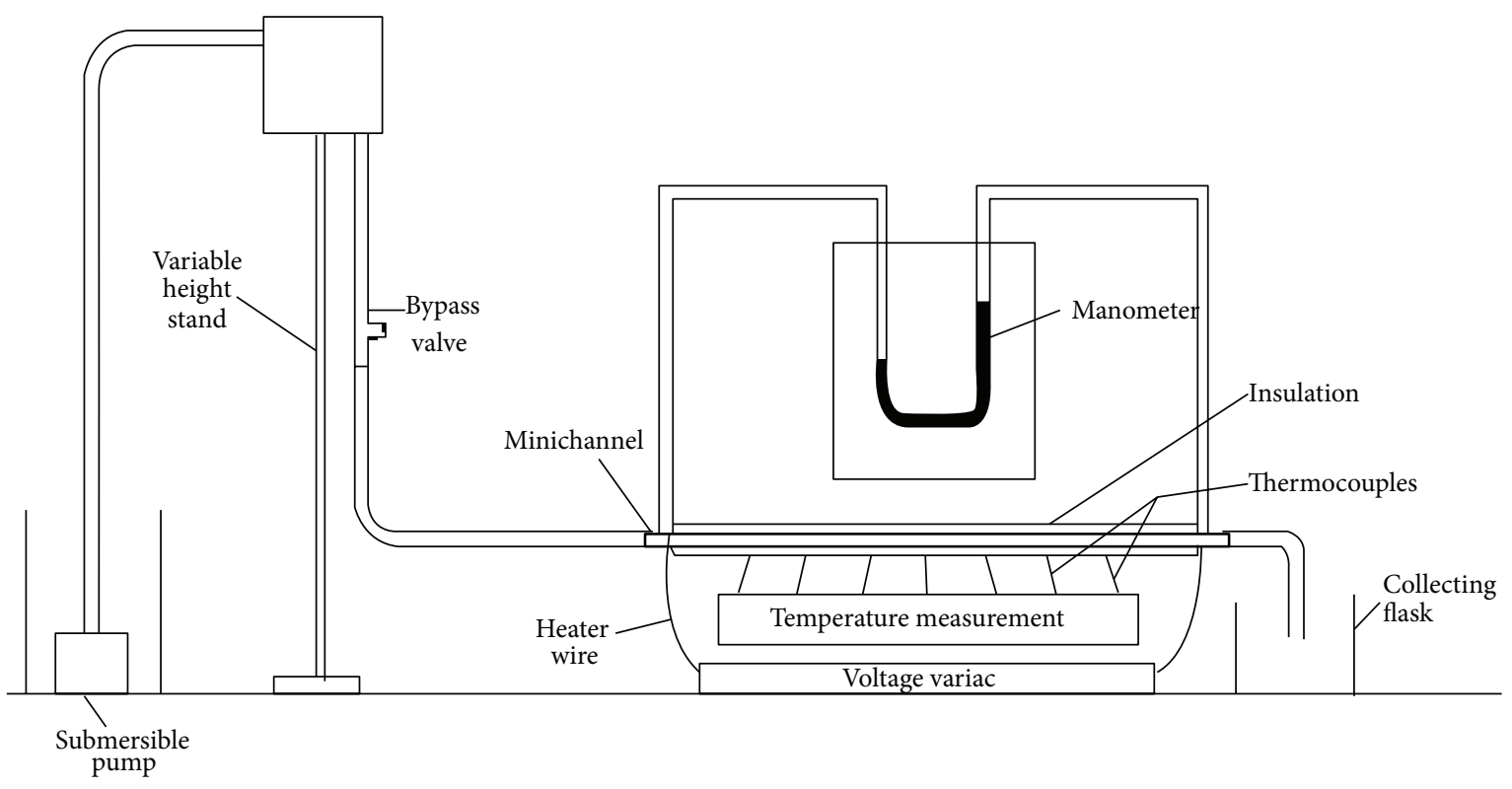

FIGURE 1: Experimental setup.

for nanofluids accurately. In the following equation, $n$ is the shape factor and is equal to 3 for spherical nanoparticles:

$$
\frac{k_{n f}}{k_{f}}=\frac{k_{p}+(n-1) k_{f}-(n-1) \varphi\left(k_{f}-k_{p}\right)}{k_{p}+(n-1) k_{f}+\varphi\left(k_{f}-k_{p}\right)} .
$$

For the case when Brownian motion was considered, the thermal conductivity relation developed by Koo and Kleinstreuer [7] was used:

$$
\begin{aligned}
k_{n f}= & k_{f}+3 \varphi \frac{k_{p}-k_{f}}{2 k_{f}+k_{p}-\varphi\left(k_{p}-k_{f}\right)} k_{f}+5 \times 10^{4} \beta \rho_{f} C_{f} \varphi \\
& \times \sqrt{\frac{k_{b} T}{2 \rho_{p} r_{p}}}[(-134.63+1722.3 \varphi)+(0.4705-6.04 \varphi) T] .
\end{aligned}
$$

The parameter $\beta$ is related to the nanoparticle Brownian motion and was determined empirically as

$$
\begin{aligned}
& \beta=0.0137(100 \varphi)^{-0.8229}, \quad \text { for } \varphi<0.01 \\
& \beta=0.0011(100 \varphi)^{-0.7272}, \quad \text { for } \varphi>0.01
\end{aligned}
$$

The viscosity of the nanofluid was calculated by using the Batchelor correlation [15] as very dilute suspensions were used in this work:

$$
\mu_{n f}=\left(1+2.5 \varphi+6.2 \varphi^{2}\right) \mu_{f}
$$

This equation applies to suspensions of low particle concentrations, where particle-particle interactions are negligible.

Thermophysical properties of the nanofluids have been taken as temperature dependent for numerical simulation.
Tables 1, 2, 3, and 4 present the thermophysical properties of different nanofluids at a particular temperature $298 \mathrm{~K}$ only to show a relative comparison between different nanofluids.

2.3. Boundary Conditions and Numerical Schemes for CFD Simulation. FLUENT 6.3.26 is used for solver execution and postprocessing of the CFD simulation. Actually in CFD the control volume is divided into number of nodes (cell). Usually the accuracy of the simulation result increases with the increase in number of nodes and becomes constant at a particular value. The CFD simulations were done for 2000 cells $(20 * 100)$. The grid considered here was half cross section of a pipe. The four boundaries considered are VELOCITY INLET, WALL, PRESSURE OUTLET, and AXIS OF SYMMETRY. The nanofluid was considered as a homogeneous mixture in the simulation. The flow regime that was considered for analysis was laminar. The schemes that have been used in analysis are SIMPLE for pressure-velocity coupling, PRESTO for pressure, and second-order upwind for momentum and energy.

\section{Results and Discussions}

3.1. Results for $\mathrm{Al}_{2} \mathrm{O}_{3}$-Water Nanofluid for Laminar Flow Region. The experiment was carried out for a minichannel flow of $\mathrm{Al}_{2} \mathrm{O}_{3}$-water nanofluid in the laminar flow region. Observations were made for different volume concentrations of nanofluid-2\% and 3\%-and distilled water for $0.87 \mathrm{~mm}$ diameter minichannel. The experimental results were then compared with the results obtained by simulations carried on FLUENT 6.3.26. The wall boundary condition considered in these cases was of constant heat flux. Two cases were considered in the computational analysis-one without considering the Brownian motion and the other one by considering the 
TABLE 1: Thermophysical properties of $\mathrm{Al}_{2} \mathrm{O}_{3}$ nanofluids of different concentrations.

\begin{tabular}{|c|c|c|c|c|c|}
\hline Fluid & $\begin{array}{l}\text { Density } \\
\left(\mathrm{kg} / \mathrm{m}^{3}\right)\end{array}$ & $\begin{array}{l}\text { Specific heat } \\
(\mathrm{J} / \mathrm{kg} \cdot \mathrm{K})\end{array}$ & \multicolumn{2}{|c|}{$\begin{array}{l}\text { Thermal conductivity } \\
(\mathrm{W} / \mathrm{m} \cdot \mathrm{K})\end{array}$} & $\begin{array}{l}\text { Viscosity } \\
(\mathrm{Pa} \cdot \mathrm{s})\end{array}$ \\
\hline Water & 997.13 & 4179 & \multicolumn{2}{|c|}{0.605} & 0.00089 \\
\hline$\gamma \mathrm{Al}_{2} \mathrm{O}_{3}$ & 3970 & 765 & \multicolumn{2}{|c|}{40} & - \\
\hline \multirow{2}{*}{ Fluid } & \multirow{2}{*}{$\begin{array}{l}\text { Density } \\
\left(\mathrm{kg} / \mathrm{m}^{3}\right)\end{array}$} & \multirow{2}{*}{$\begin{array}{l}\text { Specific heat } \\
(\mathrm{J} / \mathrm{kg} \cdot \mathrm{K})\end{array}$} & \multicolumn{2}{|c|}{$\begin{array}{l}\text { Thermal conductivity } \\
(\mathrm{W} / \mathrm{m} \cdot \mathrm{K})\end{array}$} & Viscosity \\
\hline & & & $\begin{array}{l}\text { Without Brownian } \\
\text { motion }\end{array}$ & $\begin{array}{c}\text { With Brownian } \\
\text { motion }\end{array}$ & $(\mathrm{Pa} \cdot \mathrm{s})$ \\
\hline Water $+2 \% \gamma-\mathrm{Al}_{2} \mathrm{O}_{3}$ & 1056.6 & 3922 & 0.6404 & 0.6944 & 0.00093 \\
\hline Water $+3 \% \gamma-\mathrm{Al}_{2} \mathrm{O}_{3}$ & 1086.3 & 3805 & 0.6585 & 0.7072 & 0.00096 \\
\hline
\end{tabular}

TABLE 2: Thermophysical properties of $\mathrm{SiO}_{2}$ nanofluids of different concentrations.

\begin{tabular}{|c|c|c|c|c|c|}
\hline Fluid & $\begin{array}{l}\text { Density } \\
\left(\mathrm{kg} / \mathrm{m}^{3}\right)\end{array}$ & $\begin{array}{l}\text { Specific heat } \\
(\mathrm{J} / \mathrm{kg} \cdot \mathrm{K})\end{array}$ & \multicolumn{2}{|c|}{$\begin{array}{l}\text { Thermal conductivity } \\
(\mathrm{W} / \mathrm{m} \cdot \mathrm{K})\end{array}$} & $\begin{array}{l}\text { Viscosity } \\
\text { (Pa.s) }\end{array}$ \\
\hline Water & 997.13 & 4179 & \multicolumn{2}{|c|}{0.605} & 0.00089 \\
\hline $\mathrm{SiO}_{2}$ & 2200 & 773 & \multicolumn{2}{|c|}{1.38} & - \\
\hline \multirow{2}{*}{ Fluid } & \multirow{2}{*}{$\begin{array}{l}\text { Density } \\
\left(\mathrm{kg} / \mathrm{m}^{3}\right)\end{array}$} & \multirow{2}{*}{$\begin{array}{l}\text { Specific heat } \\
(\mathrm{J} / \mathrm{kg} \cdot \mathrm{K})\end{array}$} & \multicolumn{2}{|c|}{$\begin{array}{l}\text { Thermal conductivity } \\
(\mathrm{W} / \mathrm{m} \cdot \mathrm{K})\end{array}$} & Viscosity \\
\hline & & & $\begin{array}{l}\text { Without Brownian } \\
\text { motion }\end{array}$ & $\begin{array}{l}\text { With Brownian } \\
\text { motion }\end{array}$ & $(\mathrm{Pa} \cdot \mathrm{s})$ \\
\hline Water $+2 \% \mathrm{SiO}_{2}$ & 1021.2 & 4032.2 & 0.616 & 0.6886 & 0.00093 \\
\hline Water $+3 \% \mathrm{SiO}_{2}$ & 1033.2 & 3961.5 & 0.621 & 0.6866 & 0.00096 \\
\hline
\end{tabular}

TABLE 3: Thermophysical properties of $\mathrm{TiO}_{2}$ nanofluids of different concentrations.

\begin{tabular}{|c|c|c|c|c|c|}
\hline Fluid & $\begin{array}{l}\text { Density } \\
\left(\mathrm{kg} / \mathrm{m}^{3}\right)\end{array}$ & $\begin{array}{c}\text { Specific heat } \\
(\mathrm{J} / \mathrm{kg} \cdot \mathrm{K})\end{array}$ & \multicolumn{2}{|c|}{$\begin{array}{l}\text { Thermal conductivity } \\
(\mathrm{W} / \mathrm{m} \cdot \mathrm{K})\end{array}$} & $\begin{array}{l}\text { Viscosity } \\
(\mathrm{Pa} \cdot \mathrm{s})\end{array}$ \\
\hline Water & 997.13 & 4179 & \multicolumn{2}{|c|}{0.605} & 0.00089 \\
\hline $\mathrm{TiO}_{2}$ & 4156 & 692 & \multicolumn{2}{|c|}{8.4} & - \\
\hline \multirow{2}{*}{ Fluid } & \multirow{2}{*}{$\begin{array}{l}\text { Density } \\
\left(\mathrm{kg} / \mathrm{m}^{3}\right)\end{array}$} & \multirow{2}{*}{$\begin{array}{l}\text { Specific heat } \\
(\mathrm{J} / \mathrm{kg} \cdot \mathrm{K})\end{array}$} & \multicolumn{2}{|c|}{$\begin{array}{l}\text { Thermal conductivity } \\
(\mathrm{W} / \mathrm{m} \cdot \mathrm{K})\end{array}$} & Viscosity \\
\hline & & & $\begin{array}{c}\text { Without Brownian } \\
\text { motion }\end{array}$ & $\begin{array}{c}\text { With Brownian } \\
\text { motion }\end{array}$ & $(\mathrm{Pa} \cdot \mathrm{s})$ \\
\hline Water $+2 \% \mathrm{TiO}_{2}$ & 1060.3 & 3909.4 & 0.635 & 0.6878 & 0.00093 \\
\hline Water $+3 \% \mathrm{TiO}_{2}$ & 1091.9 & 3786.3 & 0.65 & 0.698 & 0.00096 \\
\hline
\end{tabular}

TABLE 4: Thermophysical properties of $\mathrm{CuO}$ nanofluids of different concentrations.

\begin{tabular}{|c|c|c|c|c|c|}
\hline Fluid & $\begin{array}{l}\text { Density } \\
\left(\mathrm{kg} / \mathrm{m}^{3}\right)\end{array}$ & $\begin{array}{l}\text { Specific heat } \\
(\mathrm{J} / \mathrm{kg} \cdot \mathrm{K})\end{array}$ & \multicolumn{2}{|c|}{$\begin{array}{l}\text { Thermal conductivity } \\
(\mathrm{W} / \mathrm{m} \cdot \mathrm{K})\end{array}$} & $\begin{array}{l}\text { Viscosity } \\
(\mathrm{Pa} \cdot \mathrm{s})\end{array}$ \\
\hline Water & 997.13 & 4179 & \multicolumn{2}{|c|}{0.605} & 0.00089 \\
\hline $\mathrm{CuO}$ & 6500 & 551 & \multicolumn{2}{|c|}{32.9} & - \\
\hline \multirow{2}{*}{ Fluid } & \multirow{2}{*}{$\begin{array}{l}\text { Density } \\
\left(\mathrm{kg} / \mathrm{m}^{3}\right)\end{array}$} & \multirow{2}{*}{$\begin{array}{l}\text { Specific heat } \\
(\mathrm{J} / \mathrm{kg} \cdot \mathrm{K})\end{array}$} & \multicolumn{2}{|c|}{$\begin{array}{l}\text { Thermal conductivity } \\
(\mathrm{W} / \mathrm{m} \cdot \mathrm{K})\end{array}$} & Viscosity \\
\hline & & & $\begin{array}{l}\text { Without Brownian } \\
\text { motion }\end{array}$ & $\begin{array}{l}\text { With Brownian } \\
\text { motion }\end{array}$ & $(\mathrm{Pa} \cdot \mathrm{s})$ \\
\hline Water $+2 \% \mathrm{CuO}$ & 1107.2 & 3753 & 0.64 & 0.682 & 0.00093 \\
\hline Water $+3 \% \mathrm{CuO}$ & 1162.2 & 3570.3 & 0.658 & 0.696 & 0.00096 \\
\hline
\end{tabular}




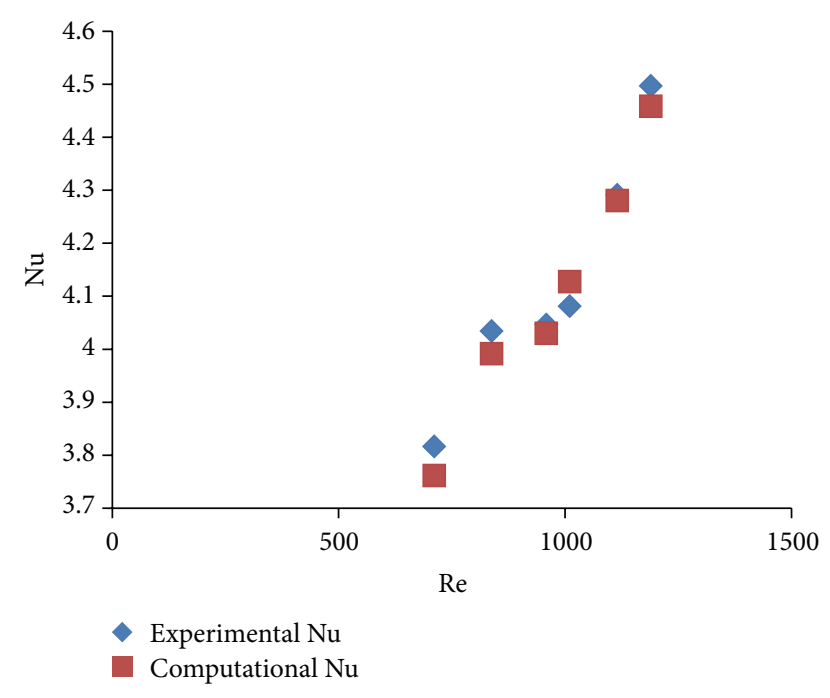

FIGURE 2: Nusselt number versus Reynolds number for $0.87 \mathrm{~mm}$ IDtube and water.

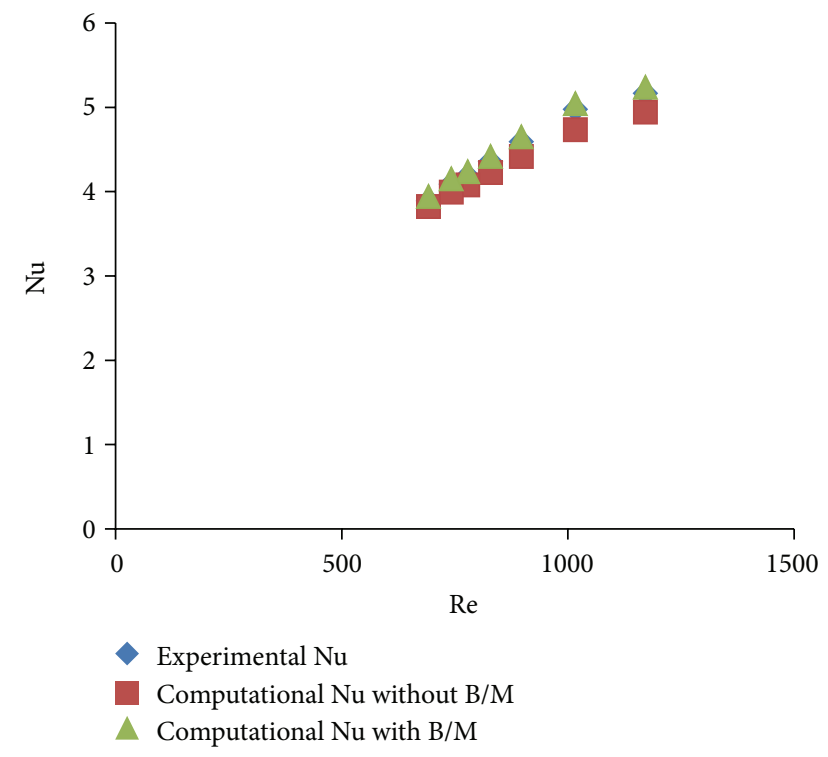

FIGURE 3: Nusselt number versus Reynolds number for $0.87 \mathrm{~mm}$ IDtube and $2 \% \mathrm{Al}_{2} \mathrm{O}_{3}$-water nanofluid.

Brownian motion. The range of Reynolds number considered for analysis was 700-1200.

The graphs for Nusselt number versus Re and friction factor versus Re for different volume concentrations of nanoparticles for $0.87 \mathrm{~mm}$ minichannel diameter are given below.

Figures 2, 3, and 4 show that the Nusselt number decreases with increase in Reynolds number as is the case theoretically. From the values of Nusselt number from graphs for different volume concentration of nanoparticles, it is evident that the value of friction factor is the highest for $3 \%$ volume concentration of nanoparticles and goes on decreasing as we decrease the volume concentration of nanoparticles.

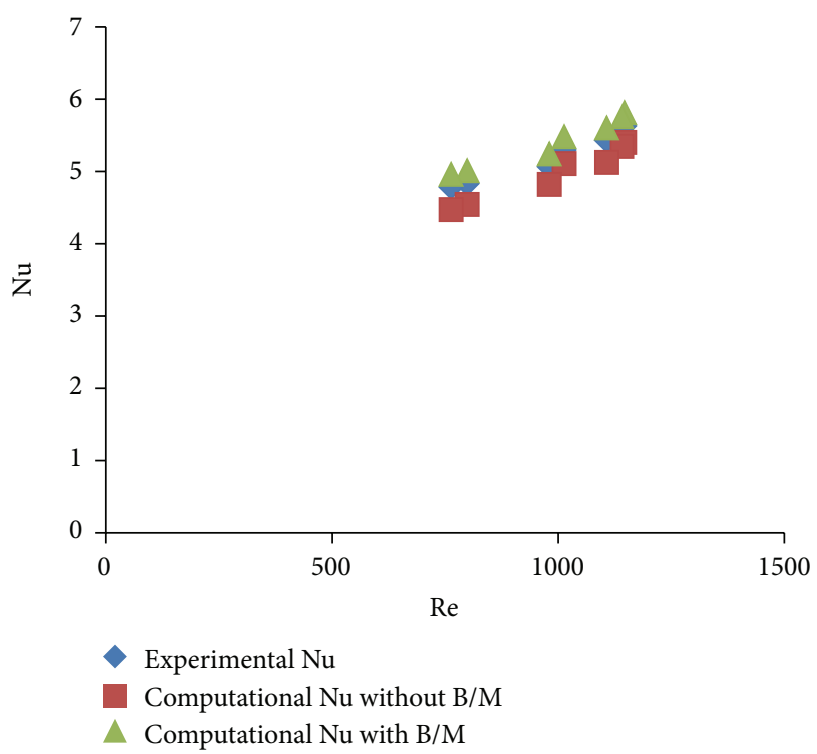

FIGURE 4: Nusselt number versus Reynolds number for $0.87 \mathrm{~mm}$ IDtube and $3 \% \mathrm{Al}_{2} \mathrm{O}_{3}$-water nanofluid.

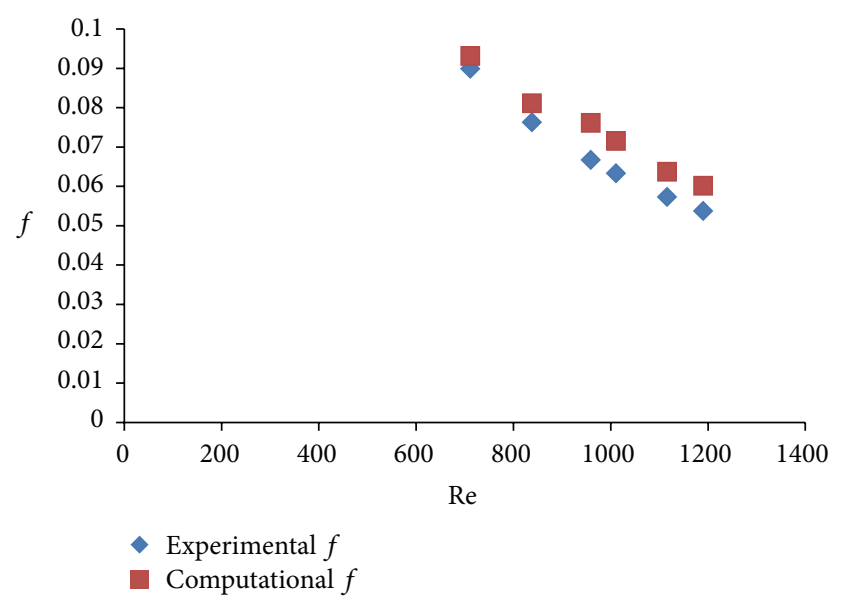

FIGURE 5: Friction factor versus Reynolds number for $0.87 \mathrm{~mm}$ IDtube and water.

Figures 5, 6, and 7 show that the friction factor decreases with increase in Reynolds number as is the case theoretically. From the values of friction factor from graphs for different volume concentration of nanoparticles, it is evident that the value of friction factor is the highest for 3\% volume concentration of nanoparticles and goes on decreasing as we decrease the volume concentration of nanoparticles. The agreement in experimental and computational results of Nusselt number and friction factor also validates the computational analysis.

3.2. Results for $\mathrm{SiO}_{2}$-Water Nanofluid, $\mathrm{TiO}_{2}$-Water Nanofluid, and $\mathrm{CuO}$-Water Nanofluid for Laminar Flow Region. After the prediction of the experimental results for the $\mathrm{Al}_{2} \mathrm{O}_{3}$ water nanofluid, computational analysis was done for the $\mathrm{SiO}_{2}$-water nanofluid, $\mathrm{TiO}_{2}$-water nanofluid, and $\mathrm{CuO}$-water 


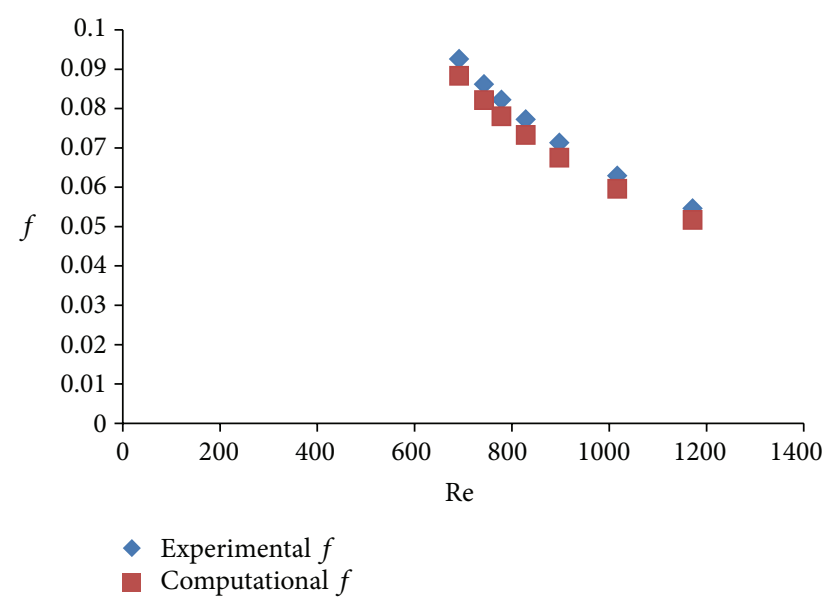

FIGURE 6: Friction factor versus Reynolds number for $0.87 \mathrm{~mm}$ IDtube and $2 \% \mathrm{Al}_{2} \mathrm{O}_{3}$-water nanofluid.

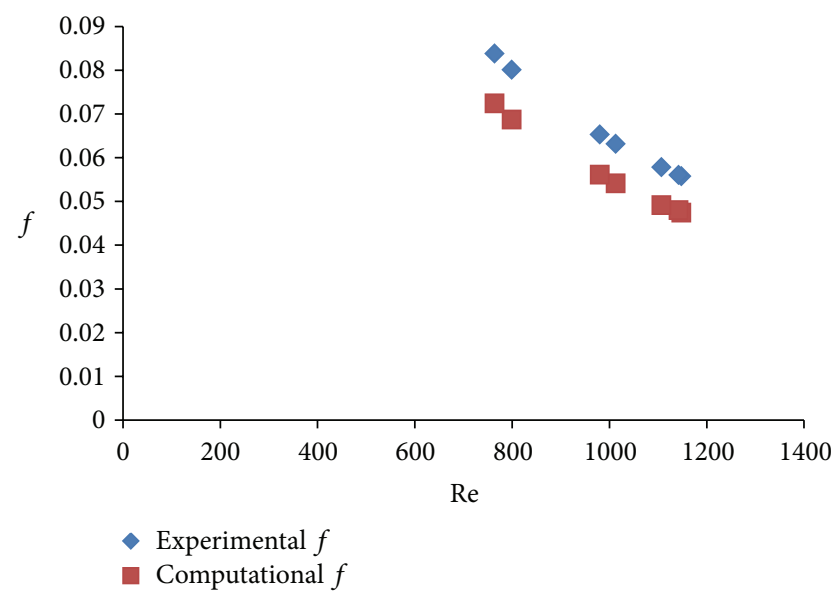

FIGURE 7: Friction factor versus Reynolds number for $0.87 \mathrm{~mm}$ IDtube and $3 \% \mathrm{Al}_{2} \mathrm{O}_{3}$-water nanofluid.

nanofluid to predict the heat transfer characteristics. The wall boundary condition considered in these cases was of constant heat flux. The heat flux values were obtained from the experimental results for $\mathrm{Al}_{2} \mathrm{O}_{3}$-water nanofluid.

Figure 8 shows that the computational results for $\mathrm{Nu}$ for $\mathrm{SiO}_{2}$ are lower than that of $\mathrm{TiO}_{2}$, which in turn is lower than $\mathrm{Nu}$ results of $\mathrm{CuO}$ for $2 \%$ volume concentration. The reason for this is that the thermal conductivity increases in the order from $\mathrm{CuO}, \mathrm{TiO}_{2}$ to $\mathrm{SiO}_{2}$ for $2 \%$ volume concentration.

Figure 9 shows that the computational results for $\mathrm{Nu}$ for $\mathrm{SiO}_{2}$ are higher than that of $\mathrm{CuO}$, which in turn is higher than $\mathrm{Nu}$ results of $\mathrm{TiO}_{2}$ for $3 \%$ volume concentration. The reason for this is that the thermal conductivity decreases in the order from $\mathrm{TiO}_{2}, \mathrm{CuO}$ to $\mathrm{SiO}_{2}$ for $3 \%$ volume concentration.

\section{Conclusions}

Minichannel flow of nanofluids has been predicted considering nanofluid as a single phase homogeneous mixture. The homogeneous mixture model for the nanofluid holds good

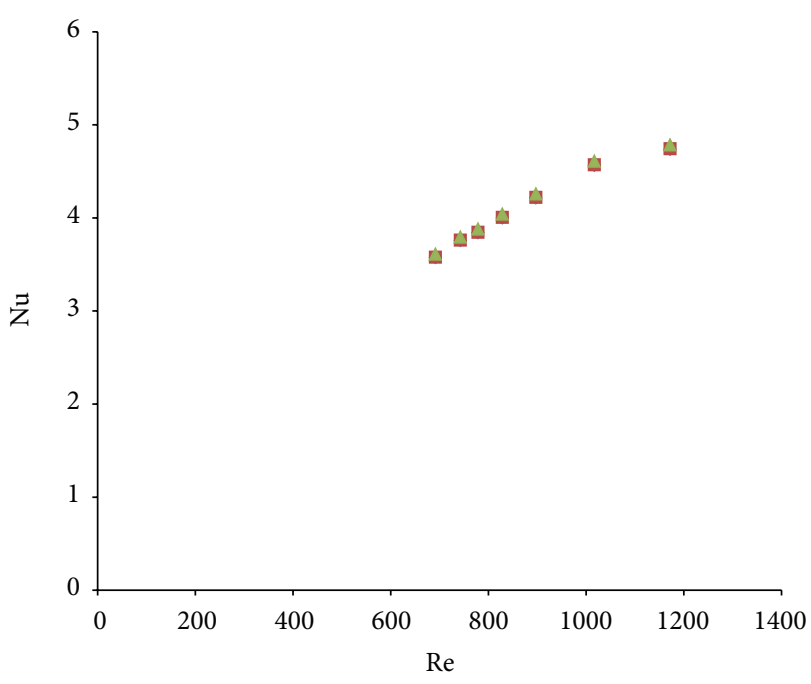

$\mathrm{Nu}$ for $\mathrm{SiO}_{2}$

$\mathrm{Nu}$ for $\mathrm{TiO}_{2}$

$\triangle \mathrm{Nu}$ for $\mathrm{CuO}$

FIGURE 8: Nusselt number versus Reynolds number for $0.87 \mathrm{~mm}$ IDtube and $2 \%$ nanofluid.

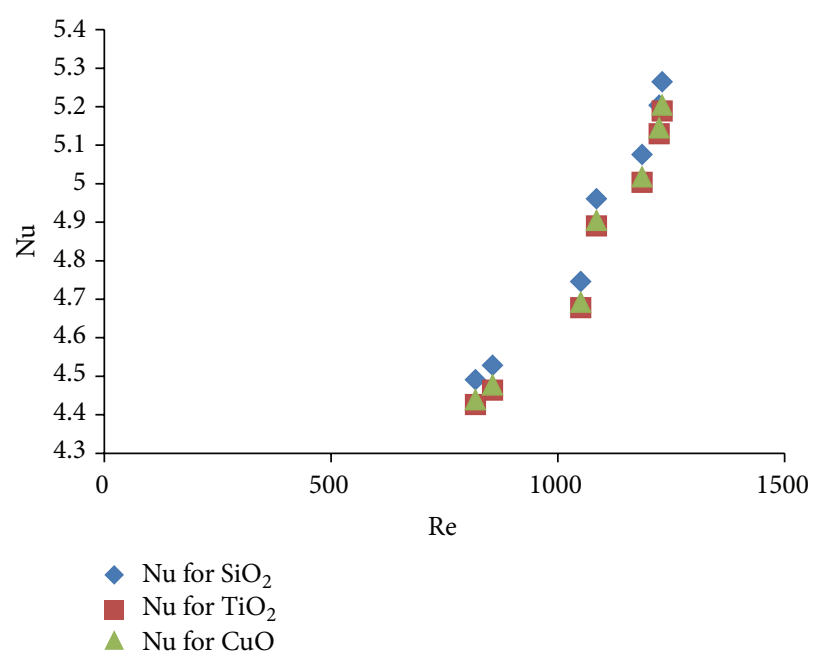

FIGURE 9: Nusselt number versus Reynolds number for $0.87 \mathrm{~mm}$ IDtube and $3 \%$ nanofluid.

to predict the average Nusselt number and friction factor in case of laminar flow. Hence, the present computational model can be a good alternative approach to predict heat transfer and pressure drop characteristics of minichannel flow using nanofluids. Also, the error in prediction of Nusselt number is less if we consider Brownian motion in our computational model, which is within $4 \%$. The increase in Nusselt number for $2 \%$ volume concentration of nanoparticles is nearly $15 \%$ for $\mathrm{Al}_{2} \mathrm{O}_{3}, 5 \%$ for $\mathrm{SiO}_{2}, 5.5 \%$ for $\mathrm{TiO}_{2}$, and $6.5 \%$ for $\mathrm{CuO}$. The increase in Nusselt number for $3 \%$ volume concentration of nanoparticles is nearly $23 \%$ for $\mathrm{Al}_{2} \mathrm{O}_{3}, 16 \%$ for $\mathrm{SiO}_{2}, 14 \%$ for $\mathrm{TiO}_{2}$, and $14.5 \%$ for $\mathrm{CuO}$.

It has been observed that nanofluids can be used in many applications due to the enhancement in heat transfer. By 
using nanofluids, the heat exchanging devices especially in electronic cooling applications may be made more energy efficient and compact. Although the exact mechanism of heat transfer by nanofluids is still unclear and there are challenges like nanofluids stability and production cost, it has a promising future in industry applications.

\section{Nomenclature}

$\rho_{n f}:$ Density of the nanofluid

$\varphi$ : Volume concentration of nanoparticles in nanofluid

$\rho_{f}$ : Density of the base fluid

$\rho_{p}:$ Density of the nanoparticles

$C_{n f}$ : Specific heat of the nanofluid

$C_{f}$ : Specific heat of the base fluid

$k_{n f}$ : Thermal conductivity of the nanofluid

$k_{f}$ : Thermal conductivity of the base fluid

$n$ : $\quad$ Shape factor of the nanoparticles

$\mu_{n f}$ : Viscosity of the nanofluid

$\mu_{f}$ : Viscosity of the base fluid

Nu: Nusselt number

Re: Reynolds number.

\section{Conflict of Interests}

The authors declare that there is no conflict of interests regarding the publication of this paper.

\section{References}

[1] S. U. S. Choi, "Enhancing thermal conductivity of fluids with nanoparticles," in Developments and Applications of NonNewtonian Flows, D. A. Siginer and H. P. Wang, Eds., vol. 231, pp. 99-105, ASME, New York, NY, USA, 1995.

[2] G. P. Peterson and C. H. Li, "Experimental investigation of temperature and volume fraction variations on the effective thermal conductivity of nanoparticle suspensions (nanofluids)," Journal of Applied Physics, vol. 99, no. 8, Article ID 084314, 2006.

[3] X.-Q. Wang and A. S. Mujumdar, "Heat transfer characteristics of nanofluids: a review," International Journal of Thermal Sciences, vol. 46, no. 1, pp. 1-19, 2007.

[4] S. K. Das, S. U. S. Choi, and H. E. Patel, "Heat transfer in nanofluids-a review," Heat Transfer Engineering, vol. 27, no. 10, pp. 3-19, 2006.

[5] L. Cheng, F. E. P. Bandarra, and J. R. Thome, "Nanofluid twophase flow and thermal physics: a new research frontier of nanotechnology and its challenges," Journal of Nanoscience and Nanotechnology, vol. 8, no. 7, pp. 3315-3332, 2008.

[6] J. Buongiorno, "Convective transport in nanofluids," Journal of Heat Transfer, vol. 128, no. 3, pp. 240-250, 2006.

[7] J. Koo and C. Kleinstreuer, "A new thermal conductivity model for nanofluids," Journal of Nanoparticle Research, vol. 6, no. 6, pp. 577-588, 2004.

[8] P. Keblinski, W. Evans, and J. Fish, "Role of Brownian motion hydrodynamics on nanofluid thermal conductivity," Applied Physics Letters, vol. 88, no. 9, Article ID 093116, 2006.

[9] M. R. Azizian, H. Ş. Aybar, and T. Okutucu, "Effect of nanoconvection due to brownian motion on thermal conductivity of nanofluids," in Proceeding of the 7th IASME/WSEAS International Conference on Heat Transfer, Thermal Engineering and
Environment (HTE'09), pp. 53-56, Moscow, Russia, August 2009.

[10] S. P. Jang and S. U. S. Choi, "Effects of various parameters on nanofluid thermal conductivity," Journal of Heat Transfer, vol. 129, no. 5, pp. 617-623, 2007.

[11] D. H. Kumar, H. E. Patel, V. R. R. Kumar, T. Sundararajan, T. Pradeep, and S. K. Das, "Model for heat conduction in nanofluids," Physical Review Letters, vol. 93, no. 14, Article ID 144301, 4 pages, 2004.

[12] H. E. Patel, T. Sundararajan, T. Pradeep, A. Dasgupta, N. Dasgupta, and S. K. Das, "A micro-convection model for thermal conductivity of nanofluids," Pramana, vol. 65, no. 5, pp. 863-869, 2005.

[13] R. L. Hamilton and O. K. Crosser, "Thermal conductivity of heterogeneous two-component systems," Industrial and Engineering Chemistry Fundamentals, vol. 1, no. 3, pp. 187-191, 1962.

[14] X. Zhang, H. Gu, and M. Fujii, "Effective thermal conductivity and thermal diffusivity of nanofluids containing spherical and cylindrical nanoparticles," Journal of Applied Physics, vol. 100, no. 4, Article ID 044325, 5 pages, 2006.

[15] G. K. Batchelor, "The effect of brownian motion on the bulk stress in a suspension of spherical particles," Journal of Fluid Mechanics, vol. 83, no. 1, pp. 97-117, 1977. 


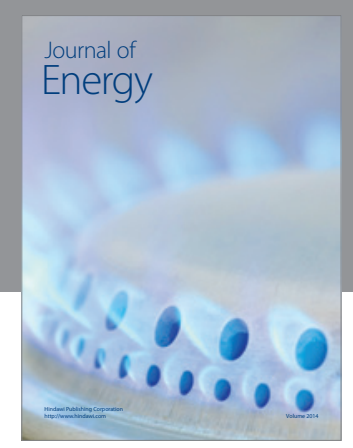

Journal of

Industrial Engineering
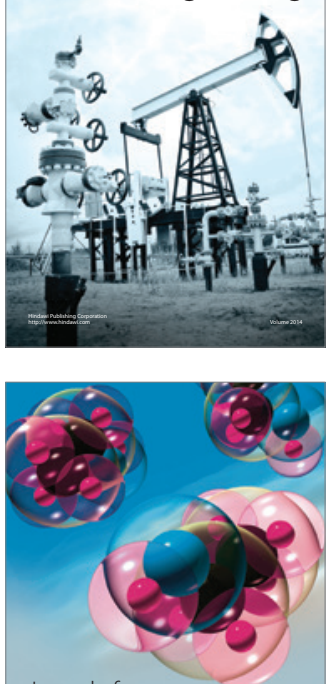

Fuels
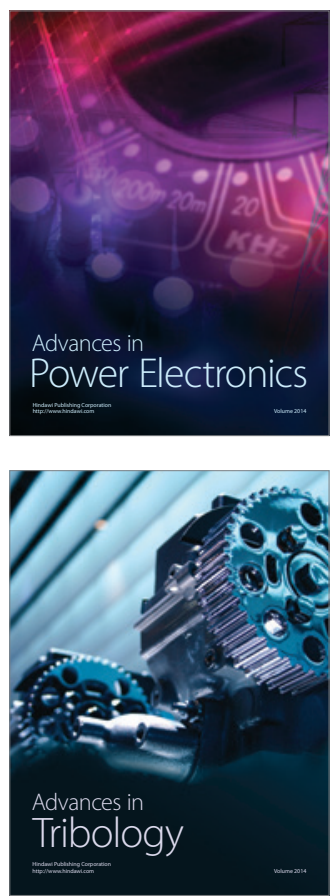

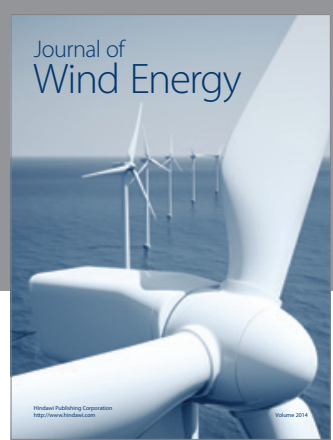

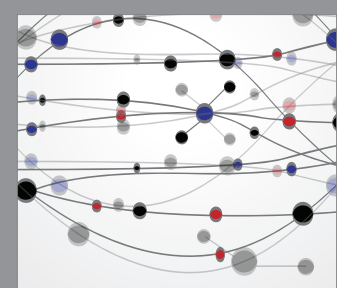

The Scientific World Journal

Submit your manuscripts at http://www.hindawi.com

Journal of

Structures
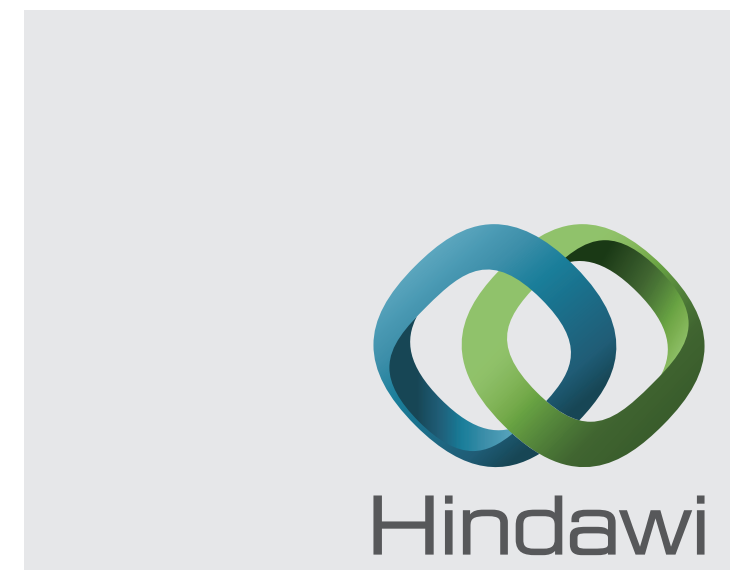

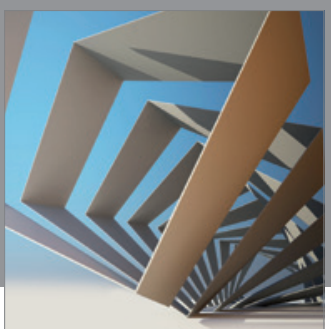

Rotating

Machinery
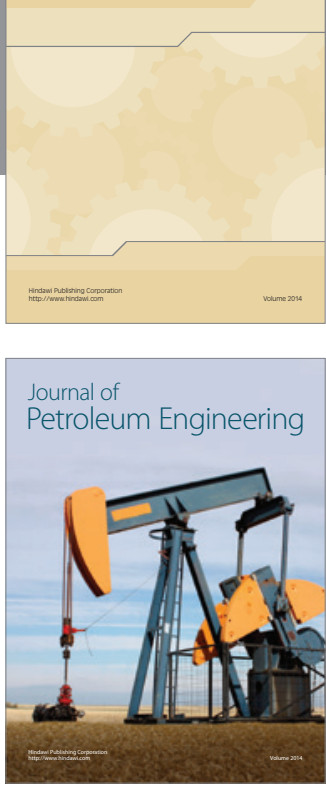

Journal of

Solar Energy
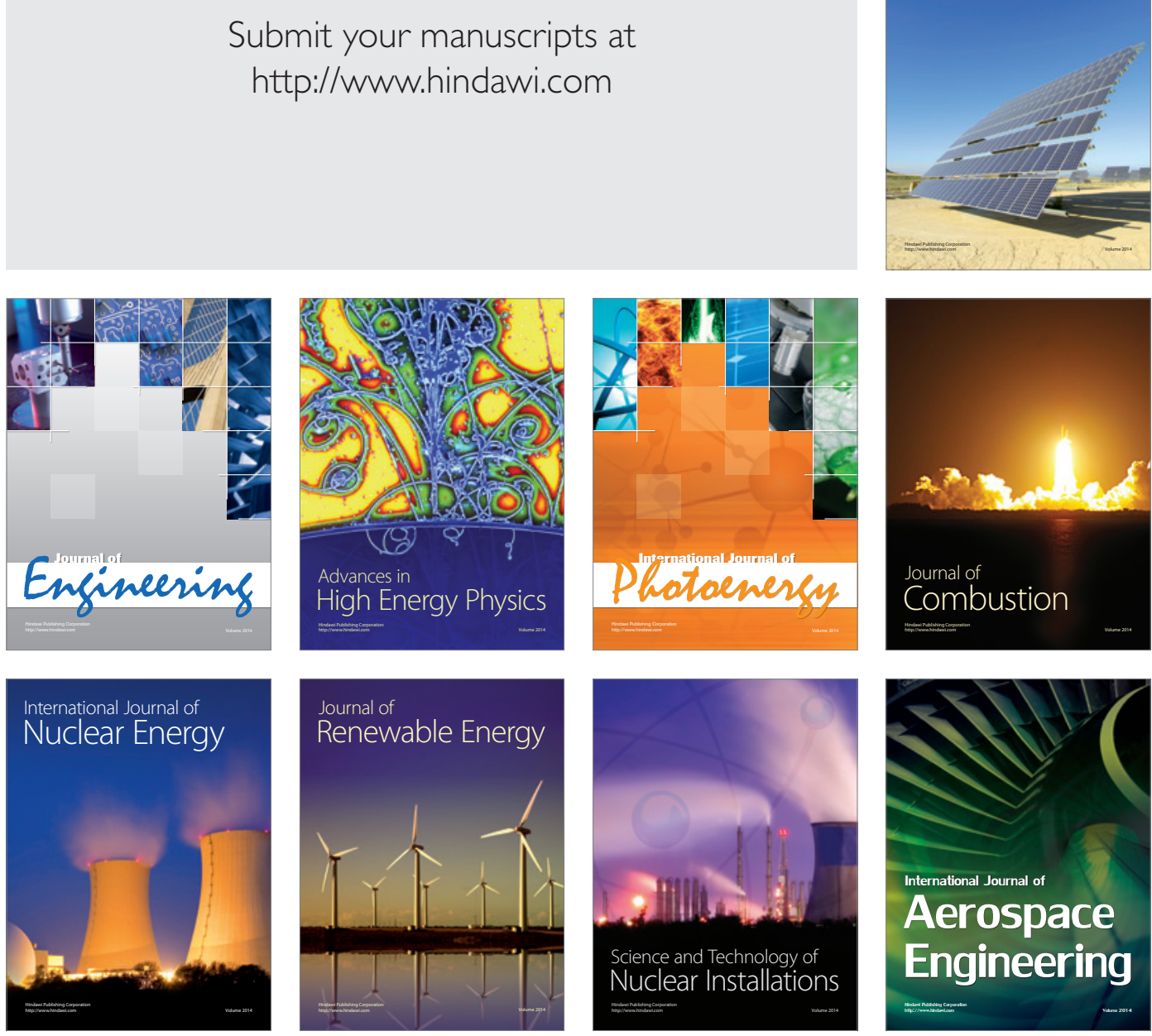